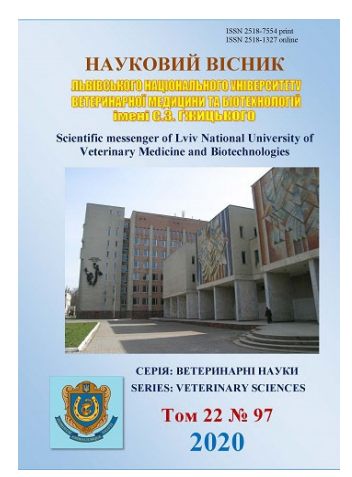

\section{Науковий вісник Аьвівського національного університету ветеринарної медицини та біотехнологій імені С.3. Гжицького. Серія: Ветеринарні науки \\ Scientific Messenger of Lviv National University of Veterinary Medicine and Biotechnologies. Series: Veterinary sciences}

ISSN 2518-7554 print ISSN 2518-1327 online doi: $10.32718 /$ nvlvet9708 https://nvlvet.com.ua/index.php/journal

UDC 619:639.2/.3.09:579.843.2

\title{
Distribution of fish apophalosis in the river basins of Sumy region
}

\author{
R. V. Petrov, V. I. Rysovanyy, F. G. Muravyov, S. M. Nazarenko \\ Sumy National Agrarian University, Sumy, Ukraine
}

\section{Article info}

Received 27.01.2020 Received in revised form 26.02.2020

Accepted 27.02.2020

Sumy National Agrarian University, G. Kondrat'eva Str., 160, Sumy, 40000, Ukraine. Tel.: +38-066-392-79-28 E-mail:romanpetrov1978@gmail.com

\begin{abstract}
Petrov, R. V., Rysovanyy, V. I., Muravyov, F. G., \& Nazarenko, S. M. (2020). Distribution of fish apophalosis in the river basins of Sumy region. Scientific Messenger of Lviv National University of Veterinary Medicine and Biotechnologies. Series: Veterinary sciences, 22(97), 43-46. doi: $10.32718 /$ nvlvet 9708
\end{abstract}

The causative agent of apophalosis (rosicotremosis) is the larva of Apofalus donicus. It is localized in the skin, scales, perch fins, rust, walleye, and some carp fishes that live in rivers flowing into the Black Sea, in the Tisza River, and in the Azov Sea estuaries. Mature trematode parasites in the small intestine the dogs, cats, foxes, some fish-eating birds (common buzzards, quarks, white storks) and humans. The purpose of the research was to conduct research to determine the incidence of fish for trematodoses and to develop measures to ensure the regimes of fish disinfection when they are detected. The research was conducted on the basis of the department of veterinary medicine, microbiology, zooghygiene and safety and quality of animal products of the Faculty of Veterinary Medicine of Sumy National Agrarian University. During the period 2018-2019, fish were caught from the rivers of the Dnieper Basin: Sula, Psla and Vorskla. The main species of fish studied are: carp - Cyprinus carpio (L.), perch - Perca fluviatilis (L.); common ruff (Gymnocephalus cernua), walleye (Sander iucioperca). A total of 321 fish were examined. Parasitological examination of the fish was carried out by the method of complete parasitological dissection, which makes it possible to conduct quantitative and qualitative accounting of all helminths affected by the fish. The autopsy of the fish was performed according to the conventional method. The incision was made from the anal fin up and forward to the gill lid just above the base of the pectoral fin. As a result of the fish studies, the larvae of trematodes were identified, which by structure were classified as Apofalus donicus. The larvae were alive, localized under the skin and moved. The overall invasion intensity for all species of fish studied was 3.64\%. In the next phase of the study we conducted experiments to determine the resistance of the larvae to different modes of freezing, salinization and heat treatment. effective for decontamination of fish meat with the presence of metacercariae are: boiling at $80{ }^{\circ} \mathrm{C}, 15$ minutes, at 100 ${ }^{\circ} \mathrm{C}, 10$ minutes; freezing $-18{ }^{\circ} \mathrm{C}, 7$ days; salting of $12 \%$ tuzluk 1 month; frying - from 15 minutes; action of microwaves $480 \mathrm{~W}, 8$ minutes, $760 \mathrm{~W}, 4$ minutes. The prevalence of apophalosis among fish of the Dnieper River basin (Sula, Psel, Vorskla) in Sumy region was established. The overall invasion intensity for all species of fish studied was $3.64 \%$. Effective for the disinfection of fish meat with the presence of Apofalus donicus metacercariae are: boiling at $80^{\circ} \mathrm{C}, 15$ minutes, at $100{ }^{\circ} \mathrm{C}, 10$ minutes; freezing $-18{ }^{\circ} \mathrm{C}, 7$ days; salting of $12 \%$ tuzluk 1 month; frying - from 15 minutes; action of microwaves $480 \mathrm{~W}, 8$ minutes, $760 \mathrm{~W}, 4$ minutes. In the future, it is planned to conduct research to determine the spread of apophalosis among cats, dogs and fish birds.

Key words: apophalosis, freshwater fish, veterinary and sanitary evaluation, safety, quality.

\section{Розповсюдження апофалозу риби в басейнах річок Сумської області}

\author{
Р. В. Петров, В. І. Рисований, Ф. Г. Муравйов, С. М. Назаренко
}

Сумський наиіональний аграрний університет, м. Суми, Україна

Збудником апофалозу (росикотремозу) є личинка Apofalus donicus. Вона локалізується в шкірі, лусиі, плавиях окуня, йоржа, судака та деяких коропових риб, що живуть у ріках, які впадають у Чорне море, в річці Тисі, лиманах Азовського моря. Статевозріла трематода паразитує у тонкому відділі кишечнику собак, кімок, лисиць, деяких рибоїдних птахів (звичайного канюка, квакв, 
білого лелеки) та людей. Метою роботи було провести дослідження для визначення захворюваності риб на трематодози й розробити заходи щчодо забезпечення режимів знезараження риби при їх виявленні. Дослідження проводили на базі кафедри ветсанекспертизи, мікробіології, зоогігієни та безпеки і якості продуктів тваринництва факультету ветеринарної медицини Сумського національного аграрного університету. Відлов риби протягом 2018-2019 років проводили з річок Дніпровського басейну: Сули, Псла та Ворскли. В результаті проведених досліджень риби були виявлені личинки трематоди, щзо за будовою були віднесені до виду Apofalus donicus. Личинки були живі, локалізувались під икірою та рухались. Загальна екстенсивність інвазії за всіма видами досліджених риб склала 3,64 \%. У зв'язку з тим, шо апофалозом можуть заразитися люди при споживанні риби з наявністю метацеркарієв Apofalus donicus, на наступному етапі дослідження нами були проведенні досліди щодо визначення стійкості личинок до різних режимів заморожування, засолювання та термічної обробки. Ефективними для знезараження м'яса риби з наявністю метацеркарієв є: проварювання при $80{ }^{\circ} \mathrm{C}-15$ хв, при $100{ }^{\circ} \mathrm{C}-10$ хв; заморожування $-18{ }^{\circ} \mathrm{C}-7$ діб; засолювання в $12 \%$ тузлуку - 1 міс.; смаження - від 15 хв; дія мікрохвиль 480 Вm-8 хв, 760 Bm-4 хв.

Ключові слова: апофалоз, прісноводна риба, ветеринарно-санітарна очінка, безпечність, якість.

\section{Вступ}

Важливим завданням, що стоїть перед ветеринарною медициною, є захист здоров'я населення від хвороб, що передаються через продукти тваринного походження. Риба, яка є цінним продуктом харчування, може стати причиною виникнення серйозних гельмінтозів людини. Вважається, що до 750 млн людей у 56 країнах світу живуть під загрозою інвазування гельмінтами у зв'язку з вживанням у їжу риби, а 40 млн - $є$ уражені.

В межах багатьох країн реєструються біогельмінтози, збудники яких передаються людині через рибу та продукти iï переробки. Представники понад 40 родин морських і прісноводних промислових гідробіонтів, що використовуються як продовольча сировина i продукти харчування, є потенційними носіями 32 видів гельмінтів, небезпечних для здоров'я людини (Romanenko et al., 2000).

Актуальність теми. У водоймах живе понад 1000 видів риб, у тому числі 250 промислових. На сьогодні важко знайти навіть поодинокі особини риб природних популяцій, вільні від гельмінтів (Davydov et al., 2006; Davydov et al., 2011; Jevtushenko, 2013; Fedorovych et al., 2019; Fedorovych \& Gutyj, 2019).

Окремі види гельмінтів сімейств Opisthorchidae, Heterophydae, Echinostomatidae класу Trematoda, що уражають прісноводну рибу, $є$ небезпечними для людини. У личинковій стадії ці гельмінти вражають м'язи та різні органи і тканини риб (Mykytiuk et al., 1994; Romanenko et al., 2000; Fotina et al., 2017).

Личинки трематоди - це збудники опісторхозу, метагонімозу, меторхозу, нанофієтозу, псевдамфістомозу гетерофіозу й апофалозу, вони активно проникають в організм риби та розвиваються до інвазійної стадії - метацеркаріїв. Отже, риба є проміжним хазяїном.

Збудником апофалозу (росикотремозу) є личинка Apofalus donicus. Вона локалізується в шкірі, лусці, плавцях окуня, йоржа, судака та деяких коропових риб, що живуть у ріках, які впадають у Чорне море, в річці Тисі, лиманах Азовського моря. Статевозріла трематода паразитує у тонкому відділі кишечнику собак, кішок, лисиць, деяких рибоїдних птахів (звичайного канюка, квакв, білого лелеки) та людей (Davydov et al., 2006; Yatsenko et al., 2017).

Метою роботи було провести дослідження для визначення захворюваності риб на трематодози й розробити заходи щодо забезпечення режимів знезаражен- ня риби при їх виявленні. Для досягнення поставленої мети необхідно було вирішити такі завдання:

1. Встановити зараженість трематодозами прісноводної риби Дніпровського басейну на території Сумщини.

2. Встановити ефективні режими знезараження риби при апофалозі.

\section{Матеріал і методи досліджень}

Дослідження проводили на базі кафедри ветсанекспертизи, мікробіології, зоогігієни та безпеки і якості продуктів тваринництва факультету ветеринарної медицини Сумського національного аграрного університету. Відлов риби протягом 2018-2019 років проводили з річок Дніпровського басейну: Сули, Псла та Ворскли в районах сіл Червоне, Низи, Косівщина, Торопилівка, В. Рибиці Сумського району, М. Ворожба Лебединського району, Климентово Тростянецького району Сумської області. Основні види досліджених риб: сазан - Cyprinus carpio (L.), окунь Perca fluviatilis (L.); йорж звичайний (Gymnocephalus cernua), судак (Sander iucioperca). Усього було досліджено 321 екземпляр риби.

Паразитологічне дослідження риби проводили методом повного паразитологічного розтину, який дає можливість провести кількісний та якісний облік усіх гельмінтів, котрими уражена риба. Розтин риби проводили за загальноприйнятою методикою. При цьому робили розріз від анального плавця вгору та вперед до зябрової кришки трохи вище основи грудного плавця (Mykytiuk et al., 1994).

Також нами було проведено визначення стійкості метацеркаріїв Apofalus donicus до різних фізичних i хімічних факторів, при цьому проводили контроль за життєздатністю личинок, а саме: за морфологічними ознаками і руховою активностю, хімічним впливом (використовували жовч). Відсутність протягом 15 хвилин будь-якої рухової реакції, порушення морфологічної структури i пожовтіння метацеркаріїв свідчили про їхню нежиттєздатність.

\section{Результати та їх обговорення}

В результаті проведених досліджень риби були виявлені личинки трематоди, що за будовою були віднесені до виду Apofalus donicus. Личинки були живі, локалізувались під шкірою та рухалися (рис. 1). 

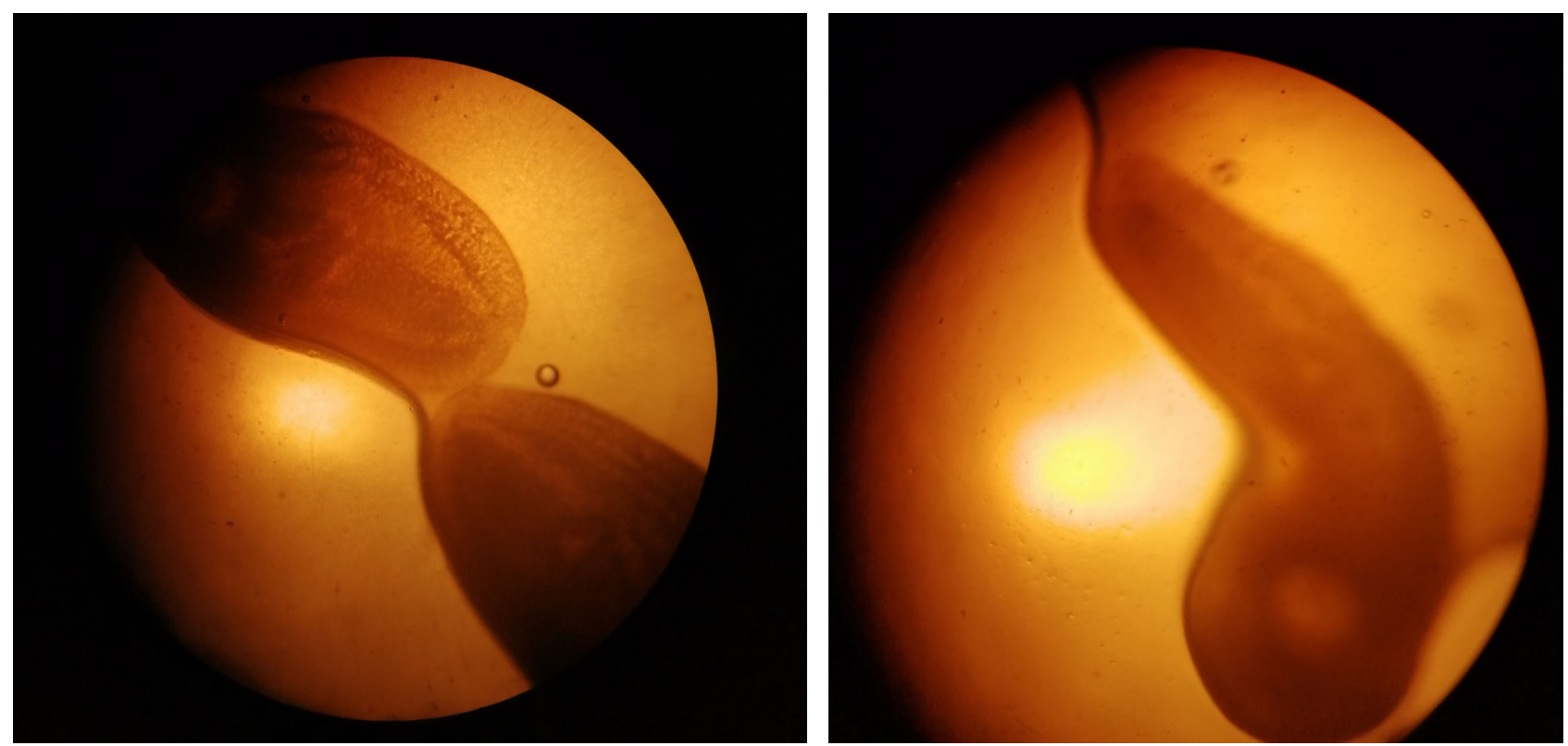

Рис. 1. Виявлені личинки Apofalus donicus під шкірою йоржа $(\times 120)$

Таблиця 1

Поширеність апофалозу серед риб басейну річок Дніпра (Сула, Псел, Ворскла ) в Сумської області

\begin{tabular}{|c|c|c|c|c|}
\hline $\begin{array}{l}\text { Вид } \\
\text { риби }\end{array}$ & $\begin{array}{c}\text { Кількість досліджених } \\
\text { екземплярів }\end{array}$ & $\begin{array}{c}\text { Кількість позитивних } \\
\text { результатів на апофалоз }\end{array}$ & $\begin{array}{c}\text { Екстенсивність ураження, } \\
\text { \% }\end{array}$ & $\begin{array}{c}\text { Інтенсивність ураження, } \\
\text { екземплярів }\end{array}$ \\
\hline \multicolumn{5}{|c|}{ р. Сула } \\
\hline Сазан & 8 & - & 0 & - \\
\hline Окунь & 47 & 2 & 4,25 & $3-7$ \\
\hline Йорж & 39 & 1 & 2,56 & 8 \\
\hline Судак & 18 & 1 & 5,55 & 7 \\
\hline \multicolumn{5}{|c|}{ p. Псел } \\
\hline Сазан & 9 & 1 & 11,1 & 11 \\
\hline Окунь & 51 & 1 & 1,96 & 10 \\
\hline Йорж & 41 & 3 & 7,31 & $8-11$ \\
\hline Судак & 21 & 2 & 9,52 & $7-14$ \\
\hline \multicolumn{5}{|c|}{ р. Ворскла } \\
\hline Сазан & 7 & - & 0 & - \\
\hline Окунь & 35 & 1 & 2,85 & 6 \\
\hline Йорж & 29 & 2 & 6,89 & $5-9$ \\
\hline Судак & 16 & 1 & 6,25 & 7 \\
\hline
\end{tabular}

\section{Таблиця 2}

Стійкість метацеркарієв Apofalus donicus при обробці риби (n = 5)

\begin{tabular}{|c|c|c|c|}
\hline Фактори & & Режим та експозиція & \\
\hline Дія високої температури & $80^{\circ} \mathrm{C}, 5 \mathrm{xв}$ & $80^{\circ} \mathrm{C}, 10 \mathrm{xв}$ & $80^{\circ} \mathrm{C}, 15$ хв \\
\hline Результати знезараження & - & - & + \\
\hline Дія високої температури & $100{ }^{\circ} \mathrm{C}, 5 \times \mathrm{xB}$ & $100^{\circ} \mathrm{C}, 10 \times \mathrm{xв}$ & $100{ }^{\circ} \mathrm{C}, 15 \mathrm{xв}$ \\
\hline Результати знезараження & - & + & + \\
\hline Дія низької температури & $-1{ }^{\circ} \mathrm{C}, 10$ діб & $-18{ }^{\circ} \mathrm{C}, 24$ години & $-18{ }^{\circ} \mathrm{C}, 7$ діб \\
\hline Результати знезараження & - & - & + \\
\hline Дія натрію хлориду & $10 \%, 1$ міс. & $12 \%, 1$ міс. & 14\%, 1 міс. \\
\hline Результати знезараження & - & + & + \\
\hline Смаження шматків риби & $10 \mathrm{xB}$ & $15 \mathrm{xB}$ & $20 \mathrm{xB}$ \\
\hline Результати знезараження & - & + & + \\
\hline Припускання шматків риби & $10 \mathrm{xB}$ & $15 \mathrm{xB}$ & $20 \mathrm{xB}$ \\
\hline Результати знезараження & - & + & + \\
\hline Дія мікрохвиль & 480 Вт, 4 хв & 480 Вт, 6 хв & 480 Вт, 8 хв \\
\hline Результати знезараження & - & - & + \\
\hline Дія мікрохвиль & 760 Вт, 2 хв & 760 Вт, 4 хв & 760 Вт, 8 хв \\
\hline Результати знезараження & - & + & + \\
\hline
\end{tabular}

Примітка: “+”- збудник знезаражений; “-” - збудник життєздатний 
Кількість метацеркарієв Apofalus donicus коливалася залежно від виду рибу та водойми (табл. 1).

Загальна екстенсивність інвазії за всіма видами досліджених риб склала 3,64 \%.

У зв'язку з тим, що апофалозом можуть заразитися люди при споживанні риби з наявністю метацеркарієв Apofalus donicus, на наступному етапі дослідження нами були проведені досліди щодо визначення стійкості личинок до різних режимів заморожування, засолювання та термічної обробки (табл. 2).

Аналізуючи отримані результати досліджень (табл. 2), можемо зробити висновок, що ефективними для знезараження м'яса риби з наявністю метацеркарієв $\epsilon$ : проварювання при $80{ }^{\circ} \mathrm{C}-15 \mathrm{xв}$, при $100{ }^{\circ} \mathrm{C}-$ 10 хв; заморожування $-18{ }^{\circ} \mathrm{C}-7$ діб; засолювання в $12 \%$ тузлуку - 1 міс.; смаження - від 15 хв; дія мікрохвиль 480 Вт -8 хв, 760 Вт -4 хв.

\section{Висновки}

1. Встановлено поширеність апофалозу серед риб басейну річок Дніпра (Сула, Псел, Ворскла ) в Сумської області. Загальна екстенсивність інвазії за всіма видами досліджених риб склала 3,64 \%.

2. Ефективними для знезараження м'яса риби 3 наявністю метацеркарієв Apofalus donicus є: проварювання при $80{ }^{\circ} \mathrm{C}-15$ хв, при $100{ }^{\circ} \mathrm{C}-10$ хв; заморожування $-18{ }^{\circ} \mathrm{C}-7$ діб; засолювання в $12 \%$ тузлуку 1міс.; смаження - від 15 хв; дія мікрохвиль 480 Вт 8 хв, 760 Вт -4 хв.

Перспективи подальших досліджень. В подальшому планується провести дослідження щодо визначення розповсюдження апофалозу серед котів, собак та рибоїдних птахів.

\section{References}

Davydov, O. N., Neborachek, S. I., Kurovskaja, L. Ja., \& Lysenko, V. N. (2011). Jekologija parazitov ryb vodoemov Ukrainy. K.: Vestn. zool. (in Russian).

Davydov, O. N., Temnihanov, Ju. D., \& Kurovskaja, L. Ja. (2006). Kontrol' parazitov i bolezni vodnyh zhivotnyh: mirovoj opyt (obzor rekomendacij FAO i MJeB). Preprint. K.: In-t zoologii NAN Ukrainy (in Russian).

Fedorovych, O., \& Gutyj, B. (2019). State of the organism of the same year scaly carp infected by Eudiplozoon nipponicum. Scientific Messenger of LNU of Veterinary Medicine and Biotechnologies. Series: Veterinary Sciences, 21(94), 146-151. doi: $10.32718 /$ nvlvet9427.

Fedorovych, O., Gutyj, B., Fedorovych, V., \& Chornyi, I. (2019). Epizootic situation on fish invasion diseases in the waters of Ukraine. Scientific Messenger of LNU of Veterinary Medicine and Biotechnologies. Series: Veterinary Sciences, 21(96), 95-100. doi: $10.32718 /$ nvlvet9617.

Fotina, T. I., Petrov, R. V., Nazarenko, S. M., \& Fotin, A. I. (2017). Sanitarno-mikrobiolohichni pokaznyky ryby urazhenoi opistorkhozom ta rezhymy yii znezarazhennia. Problemy zooinzhenerii ta veterynarnoi me-dytsyny: zbirnyk naukovykh prats Kharkivskoi derzhavnoi zooveterynarnoi akademii. Kh.: RVV KhDZVA, 35(2), 87-91. http://repo.snau.edu.ua/ handle/123456789/6154 (in Ukrainian).

Jevtushenko, I. D. (2013). Epizootychna sytuacija shhodo parazytoziv ryb na vodnyh ob'jektah Harkivshhyny. Veterynarna medycyny, 97, 188-190. http://nbuv.gov.ua/UJRN/vetmed 20139778 (in Ukrainian).

Mykytiuk, P. V., Prosiana, V. V., \& Bukalova, N. V. (1994). Laboratornyi praktykum z biolohii, patolohii ta vetsanekspertyzy prisnovodnykh ryb [Tekst]. Bila Tserkva (in Ukrainian).

Romanenko, N. A., Padchenko, I. K., \& Chebyshev, N. V. (2000). Sanitarnaja parazitologija. M.: Medicina (in Russian).

Yatsenko, I. V., Bohatko, N. M., \& Bulhakova, N. V. (2017). Hihiiena i ekspertyza kharchovykh hidrobiontiv ta produktiv yikh pererobky. Chastyna 1 . Hihiiena i eksper-tyza rybopromyslovoi produktsii: Pidruchnyk. Kharkiv: "Dysa Plius" (in Ukrainian). 